\title{
A probabilistic approach for earthquake hazard assessment of the Province of Eskişehir, Turkey
}

\author{
A. Orhan ${ }^{1}$, E. Seyrek ${ }^{2}$, and H. Tosun ${ }^{2}$ \\ ${ }^{1}$ Eskişehir Osmangazi University, Department of Geological Eng., Eskişehir, Turkey \\ ${ }^{2}$ Eskişehir Osmangazi University, Department of Civil Engineering, Eskişehir, Turkey
}

Received: 18 July 2007 - Revised: 12 October 2007 - Accepted: 15 October 2007 - Published: 19 October 2007

\begin{abstract}
The city of Eskişehir in inner-western Turkey has experienced a destructive earthquake with $M_{s}=6.4$ in 1956 in addition to many events with magnitudes greater than 5 . It is located in a wide basin having young sedimentary units and thick alluvium soils which also include liquefiable sand materials. There is also an active fault passing beneath the city center and the groundwater level is very close to the ground surface. Approximately 600 thousand people are living in the province of Eskişehir. Therefore, the city and its vicinity have a high risk, when earthquake hazard is considered.

This paper summarizes the probabilistic seismic hazard analysis (PSHA) which was performed for the province of Eskişehir and introduces seismic hazard maps produced by considering earthquakes with magnitude $M_{s} \geq 4.0$ occurred during the last 100-years and a seismic model composed of four seismic sources. The results of PSHA show that the average peak ground acceleration (PGA) for the city center is $0.40 \mathrm{~g}$ for 10 percent probability of exceedance in 50 years, for rock site. The seismic hazard maps were obtained by means of a program of Geographic Information System.
\end{abstract}

\section{Introduction}

The seismic hazard analysis is one of the most important processes for earthquake safety assessment of structures and designing of earthquake resistant structures; the seismic forces for engineering structures depend on peak ground acceleration (PGA) and response spectra values calculated by this analysis. Any detailed seismic analysis carried out in a specific site for selection of appropriate ground motions for seismic design should take into consideration the geology, seismicity, structural setting. In other words, the multidisciplinary engineering interpretation (geophysical, geolog- ical, seismological and geotechnical) is necessary to obtain more rational based parameters for the design of earthquake resistant structures.

Two different methods are widely used for describing earthquake ground motions in geotechnical engineering. These are the deterministic seismic hazard analysis (DSHA) and the probabilistic seismic hazard analysis (PSHA). DSHA involves the development of a particular seismic scenario upon which a ground motion hazard is based. The scenario consists of the postulated occurrence of an earthquake with a specific size at a specific location. PSHA has allowed the uncertainties in the size, location and rate of recurrence of earthquakes, as well as in the variation of ground motion characteristics with earthquake size and location, to be explicitly considered in the evaluation of seismic hazards (Kramer, 1996).

Both probabilistic and deterministic methods have a role in hazard and risk analyses performed for decision-making purposes. One method may have priority over the other, depending on the seismic environment and the scope of the project (McGuire, 2001). DSHA and PSHA have been performed by different researchers in specific sites according to their project scopes and importance (Nakajima et al., 2007; Tosun et al., 2007; Simeonova et al., 2006; Ardeleanu et al., 2005; Kayabalı, 2002; Chandler et al., 2001).

In this study, PSHA methodology based on Cornell (1968) is applied for Eskişehir city and PGA values for 10 percent probability of exceedance in 50-years at rock sites are determined by using the attenuation relationships proposed by Boore et al. (1997), and Gülkan and Kalkan (2002). Finally PGA zonation maps are created for the study area by the Mapinfo software (Mapinfo, 2005) prepared on the basis of Geographic Information System.

Correspondence to: A. Orhan

(aorhan@ogu.edu.tr)

Published by Copernicus Publications on behalf of the European Geosciences Union. 


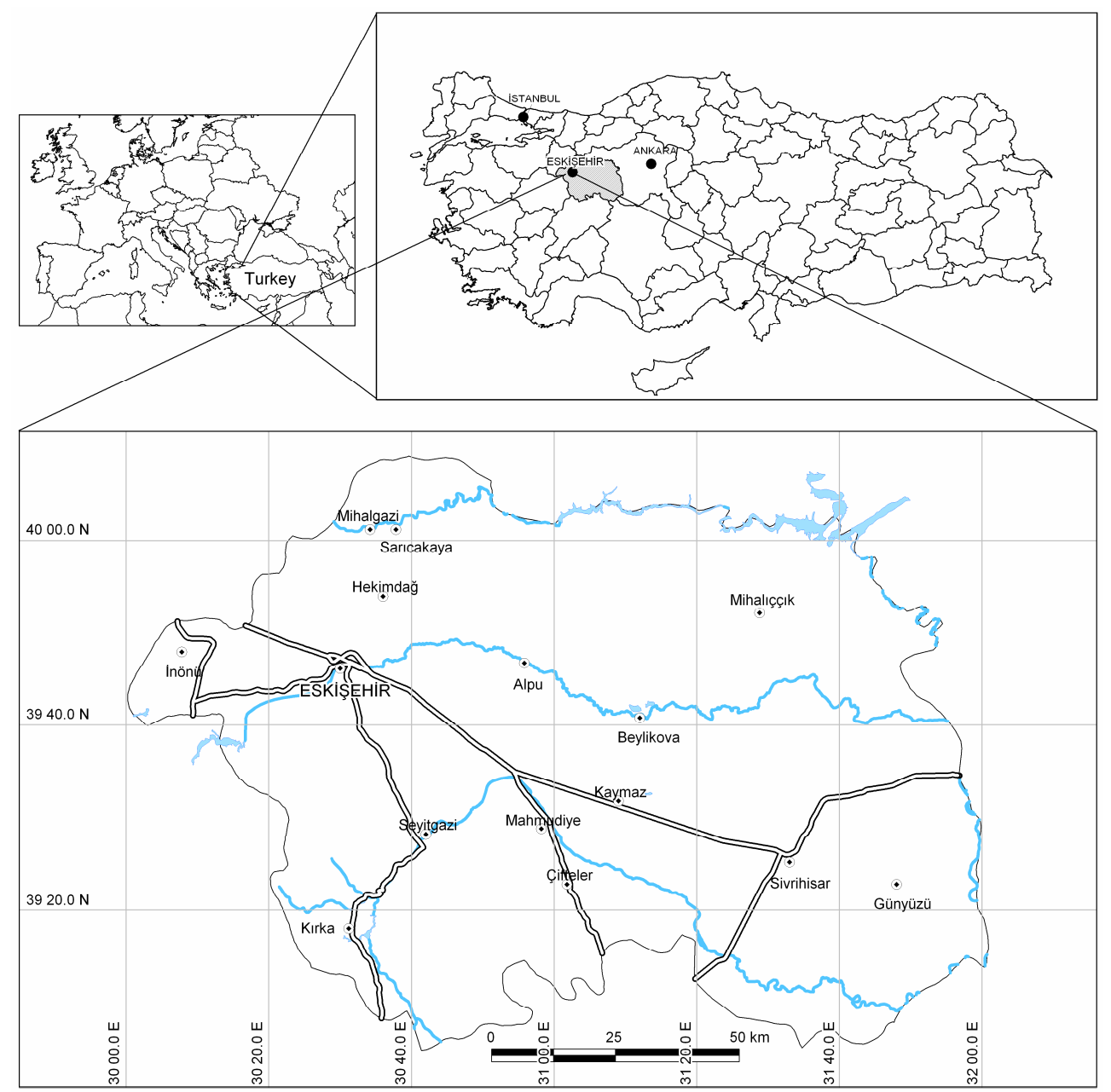

Fig. 1. Location of the study area.

\section{Location and geology}

Eskişehir is an industrialized city located in the western part of Central Anatolia Region which has a population exceeding 600 thousand habitants and covers an area of approximately $13700 \mathrm{~km}^{2}$. The (geographical) coordinates of Eskişehir city center are $30^{\circ} 30^{\prime} \mathrm{E}$ longitude and $39^{\circ} 46^{\prime} \mathrm{N}$ latitude (Fig. 1). Due to its geographical position it is the transportation center between the western and eastern parts of the country. It is also the economical center for mechanical industry.

The geological units are not complex in the province of Eskişehir. Metamorphic, volcanic and sedimentary rocks from Triassic to Quaternary age are the main geological units in the region. The generalized geological map of the city and surroundings is shown in Fig. 2. The oldest units in the North of the study area are grouped into tectonic units consisted of Triassic-aged Eskişehir Metamorphics, Karkın Formation and ophiolitic rocks. Lower Eocene-aged Mamuca Formation, Upper Miocene-aged Porsuk Formation and Pliocene-aged Ilica Formation overlie the older units.
The youngest units in the study area could be separated into two units; Pleistocene aged Akçay Formation and recent Alluvium (Gözler et al., 1996).

\section{Seismotectonics of the study area}

Eskişehir is situated within the second degree earthquake region on the seismic hazard zonation map of Turkey published by the Ministry of Reconstruction and Settlement (1996). The seismotectonics of the study area was reevaluated using earthquake records collected by the National Disaster Organization, and the map of active faults of Turkey constructed by Şaroğlu et al. (1992).

As a result of the detailed seismological survey, four seismic sources were delineated in order to determine the seismic hazard in the city area. These are North Anatolian fault zone (NAFZ), Eskişehir fault zone (EFZ), Kütahya fault zone (KFZ) and Simav fault zone (SFZ) (Fig. 3). Each fault zone is described in detail below. 


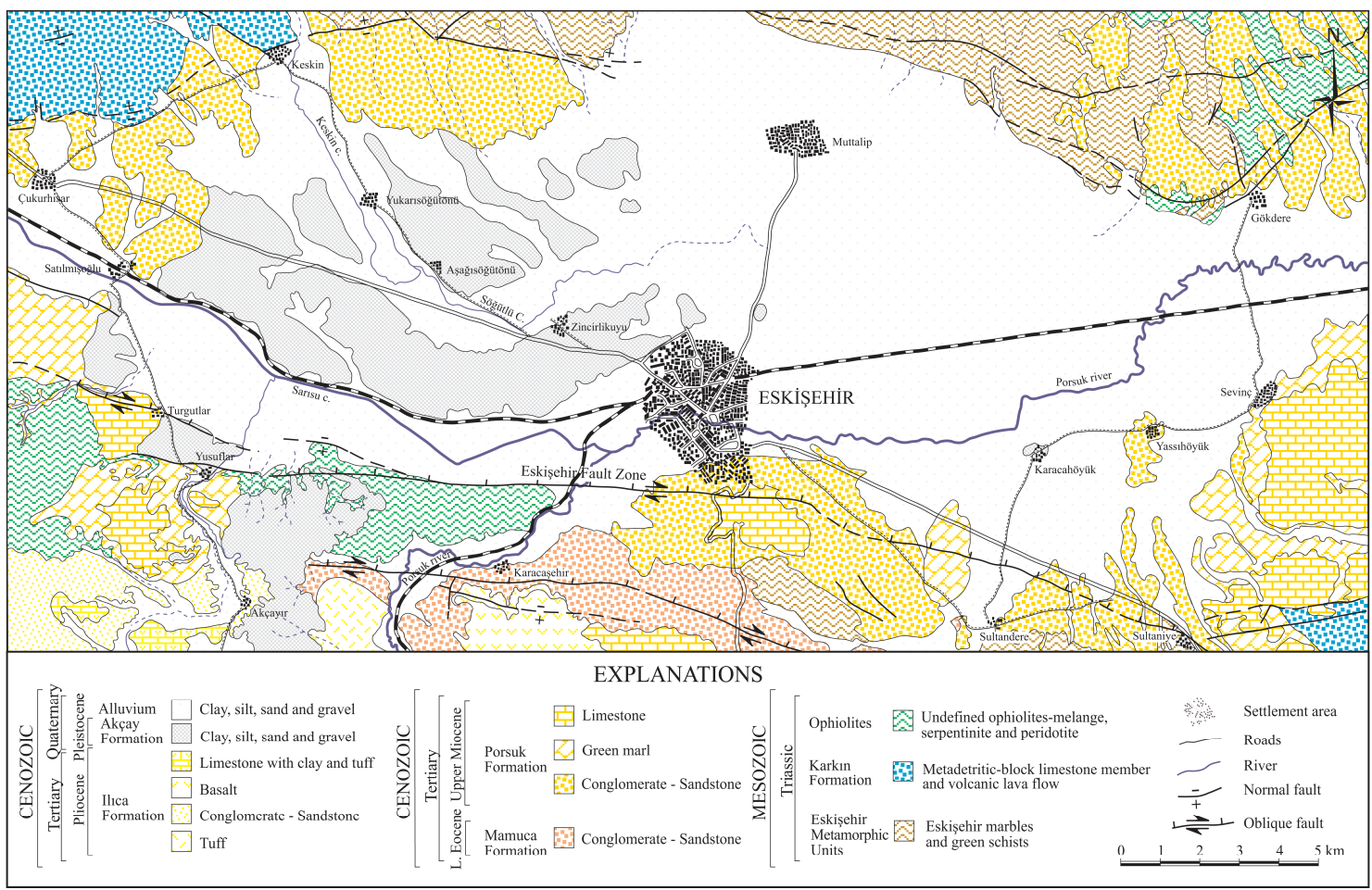

Fig. 2. Generalized geological map of Eskişehir and its vicinity (Orhan, 2005).

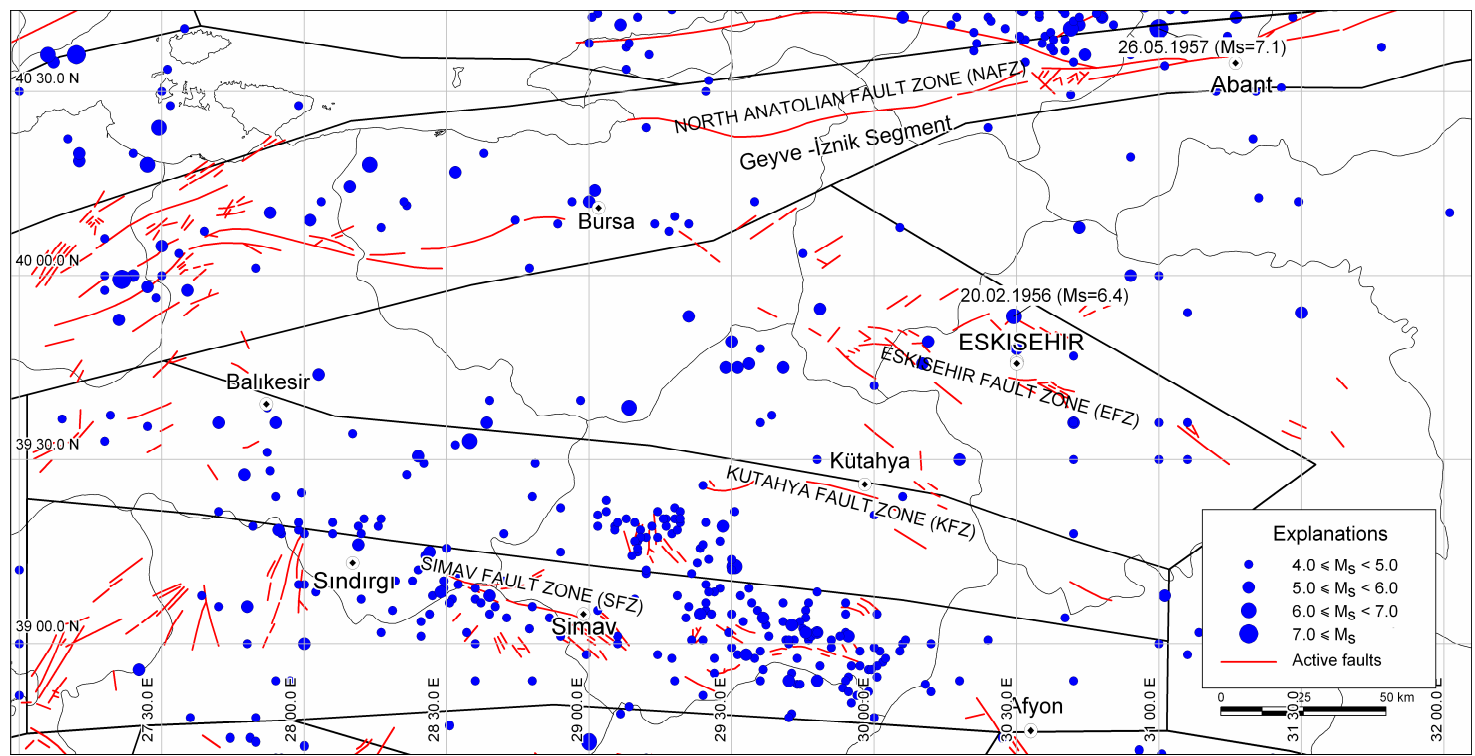

Fig. 3. Seismic sources and earthquakes occurred during the last 100 years.

The well known NAFZ is a strike-slip fault with a total length of $1400 \mathrm{~km}$ and it is divided into two branches in the Marmara Sea Region; only the southern branch was taken into account for this study. Numerous large earthquakes occurred both in recent and historical time. For the study area, one of the most important earthquakes is 1957 Abant earth- quake occurred on this segment with a magnitude of 7.1. Ambraseys (1988) reported that the earthquake was associated with a faulting extending from Northeast of Lake Abant to near Dokurçun area.

The WNW-ESE orientated Eskişehir fault zone which separates the Aegean-western Anatolian block from the central 
Table 1. Seismic hazard parameters used in this study.

\begin{tabular}{lcccccc}
\hline Source zone & Fault type* & $\begin{array}{c}\text { Observed largest } \\
\text { earthquake magnitude } \\
\text { (from 1906 to 2006) }\end{array}$ & $a$ & $b$ & $M_{\min }$ & $M_{\max }{ }^{* *}$ \\
\hline North Anatolia Fault Zone (NAFZ) & SS & 7.1 & 4.28 & 0.63 & 4.0 & 7.6 \\
Eskişehir Fault Zone (EFZ) & RLSS+N & 6.4 & 4.22 & 0.63 & 4.0 & 6.4 \\
Simav Fault Zone (SFZ) & $\mathrm{N}$ & 5.9 & 6.82 & 1.00 & 4.0 & 6.5 \\
Kütahya Fault Zone (KFZ) & $\mathrm{N}$ & 6.1 & 4.57 & 0.76 & 4.0 & 6.3 \\
\hline
\end{tabular}

* SS: Strike slip fault, RLSS: Right lateral strike slip fault, N: Normal fault

** From Ulusay et al. (2004)

Table 2. Coefficients of attenuation equation by Boore et al. (1997).

\begin{tabular}{cccccccccc}
\hline Index & $b_{1 \mathrm{SS}}$ & $b_{1 \mathrm{RV}}$ & $b_{1 \mathrm{ALL}}$ & $b_{2}$ & $b_{3}$ & $b_{5}$ & $b_{v}$ & $V_{A}(\mathrm{~m} / \mathrm{s})$ & $h(\mathrm{~km})$ \\
\hline PGA $(\mathrm{g})$ & -0.313 & -0.117 & -0.242 & 0.527 & 0.000 & -0.778 & -0.371 & 1396 & 5.57 \\
\hline
\end{tabular}

Table 3. Coefficients of attenuation equation by Gülkan and Kalkan (2002).

\begin{tabular}{cccccccc}
\hline Index & $b_{1}$ & $b_{2}$ & $b_{3}$ & $b_{5}$ & $b_{v}$ & $V_{A}(\mathrm{~m} / \mathrm{s})$ & $h(\mathrm{~km})$ \\
\hline PGA (g) & -0.682 & 0.253 & 0.036 & -0.562 & -0.297 & 1381 & 4.48 \\
\hline
\end{tabular}

Anatolian block is a right lateral strike-slip fault zone with a normal component. The fault zone is characterized by fault segments which trend from E-W to NW-SE around Eskişehir. The largest earthquake occurred on Eskişehir fault zone is the February 1956 earthquake with a magnitude of $M_{S}=6.4$. Fault plane solution of the 1956 earthquake and field observations indicate that the EFZ which played an important role in the development of Eskişehir and Inönü plains is a transtensional fault zone (Altunel and Barka, 1998).

Kütahya Fault Zone is situated at the Southwest of Eskişehir. It is composed of three main segments and each segment could be a major threat for Eskişehir. One of the most important earthquakes recorded around this fault was 1970 Çavdarhisar earthquake of magnitude 5.9, with a focal depth of $18 \mathrm{~km}$ (Genç, 2004).

Simav is one of the graben systems of the Western Anatolia, which is mainly controlled by the extensional neotectonic regime of the Aegean Region of Turkey. Simav fault trends nearly WNW-ESE for $100 \mathrm{~km}$, along the Simav River from Sindirgi at the West to Muratdagi at the East. The fault is not a single fracture; instead it consists of several step faults parallel to the main fracture (Oygür, 1997).

\section{Results of the analyses}

A probabilistic seismic hazard assessment for the province of Eskişehir is carried out, by implementing the Cornell method (Cornell, 1968). The four stages of this procedure are the characterization of seismic sources zones, estimation of seismic hazard parameters, selection of appropriate attenuation relationships, and evaluation of the hazard for the sites of interest. The last stage consists of obtaining the seismic hazard curves and seismic hazard maps. Each stage will be discussed below.

\subsection{Characterization of seismic source zones}

In Turkey various seismic source models and active fault maps have been reported previously (e.g. Yücemen, 1982; Erdik et al., 1985; Şaroğlu et al., 1992). These seismicsource models have been modified taking advantage of recent neotectonic and seismic data for Turkey. The previous studies performed by several researchers cover all country. However, large scaled areas were taken into account to obtain a database for analysis procedures by DAMHA software. The data on historical and instrumentally recorded earthquakes for Turkey and surrounding vicinity, collected from the Earthquake Research Department of the General Directorate of Disaster Affairs of Turkey (ERD, 2006) are considered as a basis of seismic hazard calculations. The 


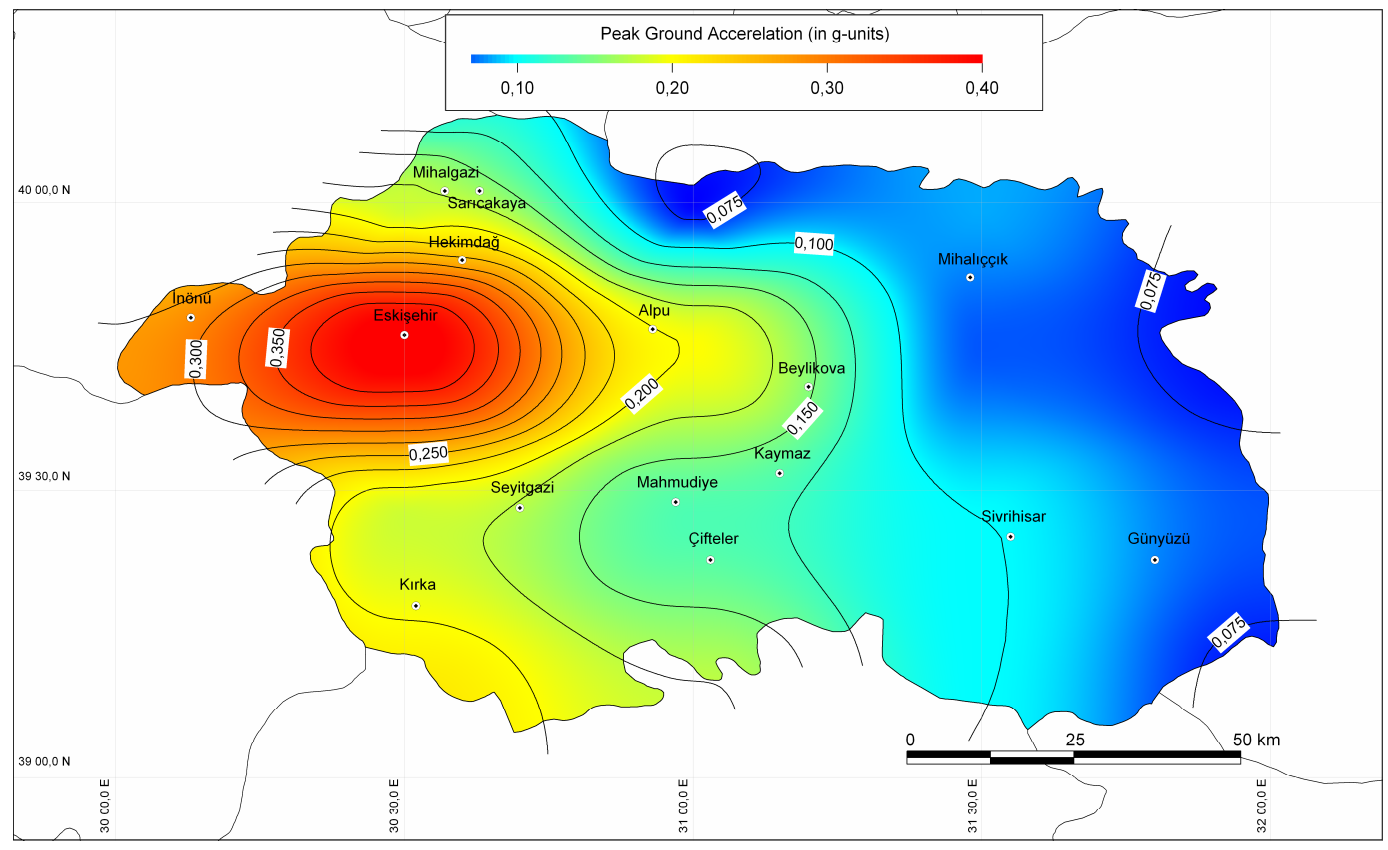

Fig. 4. Seismic hazard from all source zones for rock site based on Boore et al. (1997) attenuation relationship (475-year return period).

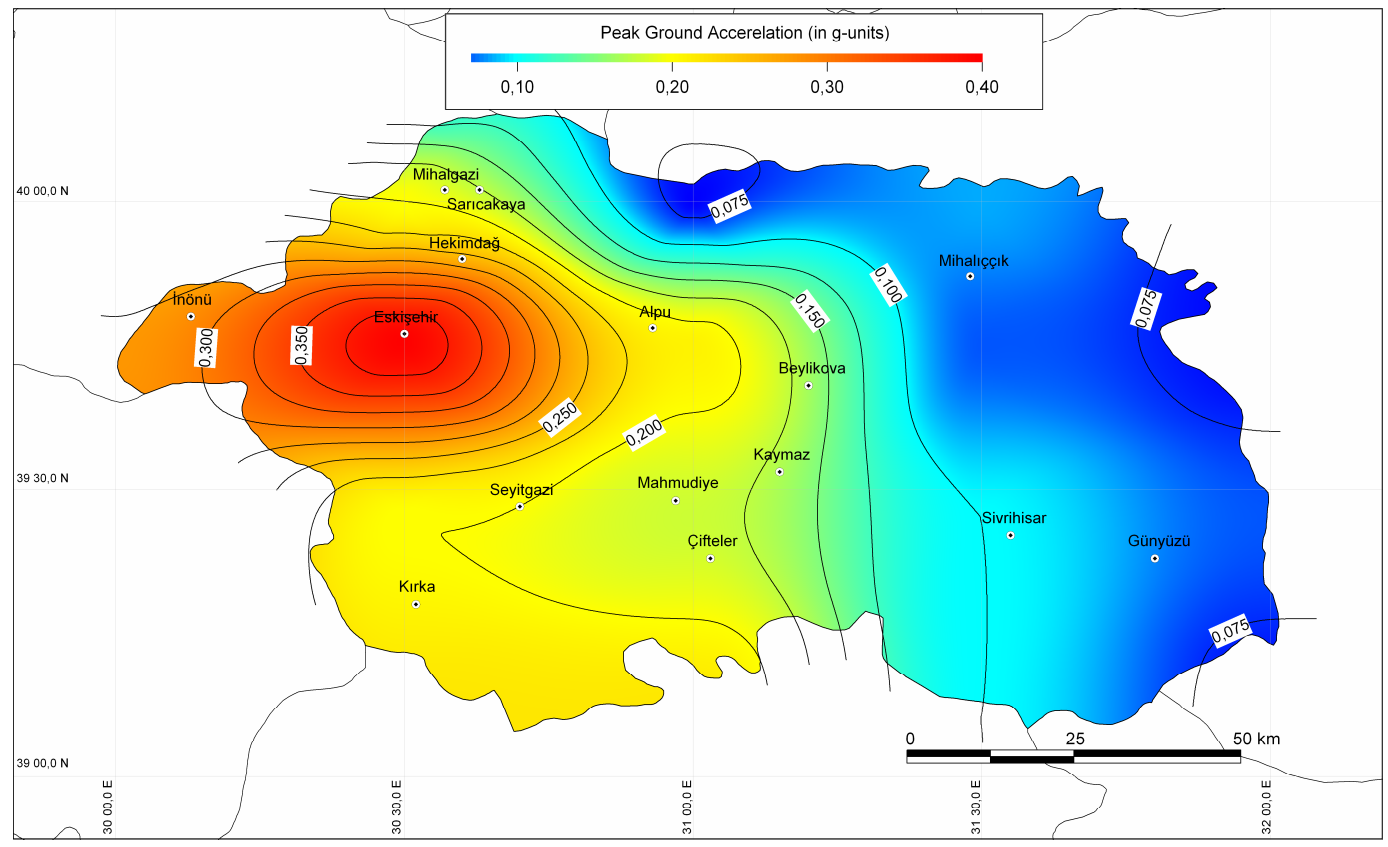

Fig. 5. Seismic hazard from all source zones for rock site based on Gülkan and Kalkan (2002) attenuation relationship (475-year return period).

earthquakes of magnitudes greater than 4.0 are included in the analyses. Four seismic sources are selected to assess the seismic hazard of Eskişehir. These are NAFZ, EFZ, KFZ, SFZ and are illustrated in Fig. 3.

\subsection{Determination of seismic hazard parameters}

One of the most important variables of source seismicity is the size (magnitude) of the maximum earthquake. The general assumption is that $1 / 3$ to $1 / 2$ of the total length of fault would rupture when it generates the maximum earthquake 


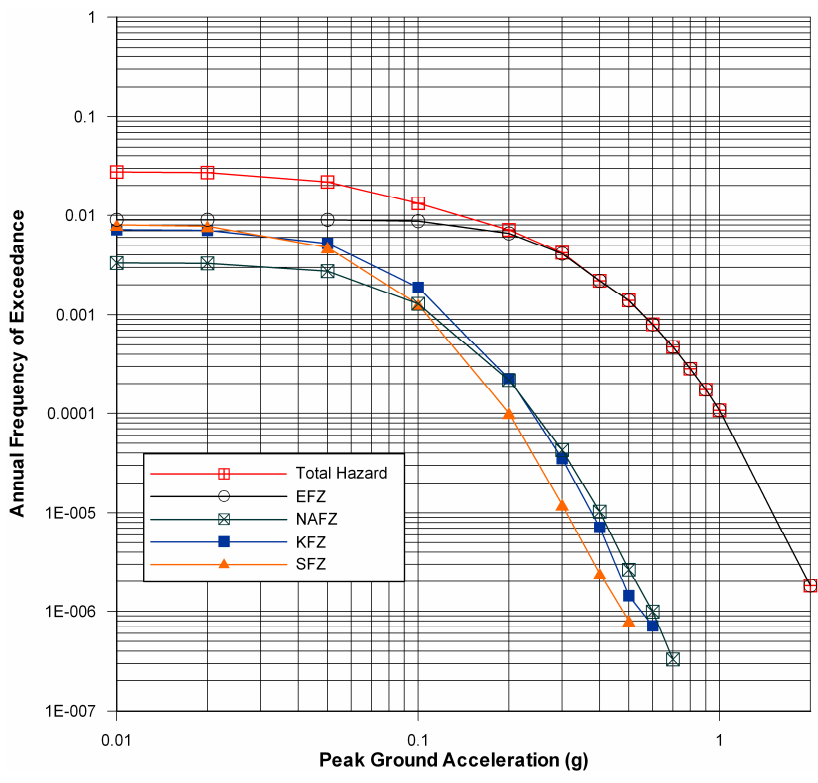

Fig. 6. Hazard contribution by source based on Gülkan and Kalkan (2002) attenuation relationship for Eskişehir city center.

(Mark, 1977). In this study, for each source the maximum earthquake magnitude is determined using the empirical relationships proposed by Wells and Coppershmith (1994) as follows:

$M_{w}=5.16+1.12 \log L$ (for strike slip faults)

$M_{w}=4.86+1.32 \log L$ (for normal faults)

Where $M_{w}$ is moment magnitude of an earthquake and $L$ is fault rupture length in $\mathrm{km}$.

Once the maximum earthquake magnitude is determined for each seismic source, a linear regression is performed to estimate the coefficients of Gutenberg-Richter (1944) relationship using the computer program DAMHA, which is developed for deterministic and probabilistic seismic hazard analyses by Earthquake Research Center of Eskişehir Osmangazi University (Table 1). In Turkish earthquake catalogue, the records which have a magnitude equal to or greater than 4.0 is more credible. The Turkish Specification suggests that the data defined above should be used for seismic studies of large engineering structures. The coefficients of the G-R law between magnitudes and their cumulative frequencies of occurrence are as follows:

$\log N_{m}=a-b M$

where $N_{m}$ is the number of earthquakes in a given period having magnitude greater than or equal to $M, a$ and $b$ are regression coefficients.

\subsection{Selection of appropriate attenuation relationship}

Due to unavailability of enough strong ground motion records for Eskişehir region, various attenuation relationships are considered (Campbell, 1981; Joyner and Boore, 1981; Boore et al., 1993, 1997; Campbell and Bozorgnia, 1994; Ambraseys, 1995; Gülkan and Kalkan, 2002). But only Boore et al. (1997) and Gülkan and Kalkan (2002) relationships are adopted for this study due to the similarities between the mechanisms of San Andreas Fault and NAF originated earthquakes. These equations give more realistic results. Because the seismic hazard level for Eskişehir by using these both relationships is compatible with different researches for Turkey and neighboring regions (Erdik et al., 1985, 1999; Ministry of Reconstruction and Settlement, 1996).

The ground motion estimation equation of Boore et al. (1997) is:

$\ln Y=b_{1}+b_{2}(M-6)+b_{3}(M-6)^{2}+b_{5} \ln r+b_{v} \ln \frac{V_{s}}{V_{A}}$

$r=\sqrt{r_{j b}^{2}+h^{2}}$

$b_{1}=\begin{array}{ll}b_{1 \mathrm{SS}} & \text { for strike slip earthquakes } \\ b_{1 \mathrm{RV}} & \text { for reverse slip earthquakes } \\ b_{1 \mathrm{ALL}} & \text { if mechanism is not specified }\end{array}$

$Y$ is the ground motion parameter (peak horizontal acceleration or pseudo-acceleration response in $\mathrm{g}$ ); $M$ is moment magnitude; $r_{j b}$ is the Joyner-Boore distance $(\mathrm{km}) ; h$ is a fictitious depth that was determined by the regression; $V_{s}$ is the average shear wave velocity to $30.0 \mathrm{~m}(\mathrm{~m} / \mathrm{s})$ and the other coefficients are presented in Table 2.

Since the general form and definitions of the variables and coefficients of Gülkan and Kalkan (2002) equation is similar with Eqs. (4-5) it is not needed to present these equations separately. Other relevant coefficients of the equation are given in Table 3.

\subsection{Evaluation of the hazard}

In order to determine the level of seismic hazard at the selected sites for Eskişehir city, a probabilistic seismic hazard methodology is applied and annual frequencies of exceedance for a number of ground motion levels are calculated with a program DAMHA. The seismic hazard curves for rock site have been developed by selected attenuation relationships. After the estimation of maximum acceleration level ( 10 percent probability of exceedance in 50-years- 475 years return period), the seismic hazard maps are created. Figure 4 shows the seismic hazard map obtained using the attenuation relationship of Boore et al. (1997) for 475-year return period. Figure 5 represents the hazard map carried out on the basis of Gülkan and Kalkan (2002) relationship. 
It came out from this study that the hazard for Eskişehir city center is mainly dominated by Eskişehir fault zone; in decreasing order, the North Anatolian, Kütahya, and Gediz Fault Zones dominate the hazard (Fig. 6).

\section{Conclusions}

As based on the probabilistic seismic hazard analysis, the following conclusions are drawn:

1. The attenuation models introduced by Boore et al. (1997) and Gülkan and Kalkan (2002) gives more realistic solutions for Eskişehir city and its vicinity.

2. For the province of Eskişehir, the hazard is mainly dominated by Eskişehir fault zone.

3. The analyses indicate that the mean PGA value for the city center of Eskişehir is about $0.40 \mathrm{~g}$ with 10 percent probability of exceedance in 50-years. The seismic hazard maps produced by this study agree with the one prepared by National Disaster Organization for the whole country, but it introduces more detail values for the investigated region.

Edited by: P. F. Biagi

Reviewed by: L. A. Ardeleanu and G. Leydecker

\section{References}

Altunel, E. and Barka, A.: Neotectonic activity of Eskişehir fault zone between İnönü and Sultandere, Geological Bulletin of Turkey, 41-2, 41-52, 1998 (in Turkish).

Ambraseys, N. N.: Engineering seismology, Earthquake Engineering and Structural Dynamics, 17, 1-105, 1988.

Ambraseys, N. N.: The prediction of earthquake peak ground acceleration in Europe, Earthquake Engineering and Structural Dynamics, 24, 467-490, 1995.

Ardeleanu, L., Leydecker, G., Bonjer, K.-P., Busche, H., Kaiser D., and Schmitt, T.: Probabilistic seismic hazard map for Romania as a basis for a new building code, Nat. Hazards Earth Syst. Sci., 5, 679-684, 2005,

http://www.nat-hazards-earth-syst-sci.net/5/679/2005/.

Boore, D. M., Joyner, W. B., and Fumal, T. E.: Estimation of response spectra and peak accelerations from western North American earthquakes: An interim report, U.S. Geol. Surv. Open-File Rept., 93-509, 72 p., 1993.

Boore, D. M., Joyner, W. B., and Fumal, T. E.: Equations for estimating horizontal response spectra and peak acceleration from Western North American earthquakes: A summary of recent work, Seismol. Res. Lett., 68, 128-153, 1997.

Campbell, K. W.: Near-source attenuation of peak horizontal acceleration, Bul. Seism. Soc. Am., 71(6), 2039-2070, 1981.

Campbell, K. W. and Bozorgnia, Y.: Near-source attenuation of peak horizontal acceleration from worldwide accelerograms recorded from 1957 to 1993, Proc. Fifth U.S. National Conference on Earthquake Engineering, 3, Chicago, Illinois, 10-14 July 1994, 283-292, 1994.
Chandler, A. M., Chan, L. S., and Lam, N. T. K.: Deterministic seismic hazard parameters and engineering risk implications for Hong Kong region, J. Asian Earth Sci., 20, 59-72, 2001.

Cornell, C. A.: Engineering seismic risk analysis, Bull. Seis. Soc. Am., 58, 1583-1606, 1968.

ERD (Earthquake Research Dept. of Turkey): http://www.sismo. deprem.gov.tr, 2006.

Erdik, M., Doyuran, V., Gülkan, P., and Akkaş, N.: Evaluation of earthquake hazard in Turkey with statistical approach. Middle East Technical University Earthquake Engineering Research Center, Ankara, 116 pp., 1985 (in Turkish).

Genç, G.: Probabilistic seismic hazard assessment for Eskişehir, METU, Graduate School of Natural and Applied Sciences, Master thesis, 154 p., 2004.

Gözler, Z., Cevher, F., Ergül, E., and Asutay, H. J.: The geology of middle Sakarya and its south, General Directorate of Mineral Research and Exploration Rep., 9973, 87 pp., 1996 (in Turkish).

Gutenberg, B. and Richter, C. F.: Frequency of earhquakes in California, Bull. Seism. Soc. Am., 34, 185-188, 1944.

Gülkan, P. and Kalkan, E.: Attenuation modeling of recent earthquakes in Turkey, J. Seismol., 6(3), 397-409, 2002.

Joyner, W. B. and Boore, D. M.: Peak horizontal acceleration and velocity from strong-motion records including records from the 1978 Imperial Valley, California earthquake, Bull. Seism. Soc. Am., 71, 2011-2038, 1981.

Kayabalı, K.: Modeling of seismic hazard for Turkey using the recent neotectonic data, Eng. Geology, 63, 221-232, 2002.

Kramer, S. L.: Geotechnical Earthquake Engineering, Prentice Hall, New Jersey, 653 pp., 1996.

Mark, R. K.: Application of linear statistical models of earthquake magnitude versus fault length in estimating maximum expectable earthquakes, Geology, 5, 464-466, 1977.

Mapinfo: Mapinfo professional ver. 8.0 user guide, Mapinfo Corporation, Troy, New York, 788 pp., 2005.

McGuire, R. K.: Deterministic vs. probabilistic earthquake hazards and risks, Soil Dynam. Earthquake Eng., 21, 377-384, 2001.

Ministry of Reconstruction and Settlement: Seismic Hazard Map of Turkey, 1996.

Nakajima, M., Choi, I., Ohtori, Y., and Choun, Y.: Evaluation of seismic hazard curves and scenario earthquakes for Korean sites based on probabilistic seismic hazard analysis, Nucl. Eng. Des., 237, 277-288, 2007.

Orhan, A.: The geo-engineering properties of foundation soils in southern part of Eskişehir city center and applying of geographic information system, Eskişehir Osmangazi Univertsity, Graduate School of Natural and Applied Sciences, Ph.D. thesis, 125 pp., 2005 (in Turkish).

Oygür, V.:, Metallogeny of the Simav Graben (Inner- Western Anatolia, Turkey), METU, Graduate School of Natural and Applied Sciences, Ph.D thesis, 144 pp., 1997.

Simeonova S. D., Solakov, D. E., Leydecker, G., Busche, H., Schmitt, T., and Kaiser, D.: Probabilistic seismic hazard map for Bulgaria as a basis for a new building code, Nat. Hazards Earth Syst. Sci., 6, 881-887, 2006, http://www.nat-hazards-earth-syst-sci.net/6/881/2006/.

Şaroğlu, F., Emre, Ö., and Kuşcu, İ.: Active Fault Map of Turkey, General Directorate of Mineral Research and Exploration, Ankara, 1992.

Tosun, H., Zorluer, İ., Orhan, A., Seyrek, E., Savaş, H., and Türköz, 
M.: Seismic Hazard and Total Risk Analyses for Large Dams in Euphrates Basin, Turkey, Engineering Geology, 89, 155-170, 2007.

Ulusay, R., Tuncay, E., Sönmez, H., and Gökçeoğlu, C.: An attenuation relationship based on Turkish strong motion data and isoacceleration map of Turkey, Eng. Geology, 74(3-4), 265-291, 2004.
Yücemen, S.: Seismic risk analysis, Middle East Technical University, Ankara, 160 pp., 1982 (in Turkish).

Wells, D. L. and Coppersmith, K. J.: New emprical relationships among magnitude, rupture length, rupture width, rupture area, and surface displacement, B. Seism. Soc. Am., 84(4), 974-1002, 1994. 